\title{
RNA 3'-terminal phosphate cyclases and cyclase-like proteins
}

\begin{abstract}
$\mathbf{R}^{\mathrm{N}}$ NA molecules bearing terminal $2^{\prime}, 3^{\prime}$-cyclic phosphate are quite common in nature. For example, $2^{\prime}, 3^{\prime}$-cyclic phosphate termini are produced during RNA cleavage by many endoribonucleases either as intermediates or final products. Many RNA-based nucleases (ribozymes) also generate cyclic phosphate termini. However, cleavage reactions are not the only way in which RNAs bearing cyclic phosphate ends are produced. They can also be generated by RNA 3'-terminal phosphate cyclases (RtcA), a family of enzymes conserved in eukaryotes, bacteria, and archaea. These enzymes catalyze the ATP-dependent conversion of the 3 '-phosphate to a $2^{\prime}, 3$ '-cyclic phosphodiester at the end of RNA. In this article, I review knowledge about the biochemistry and structure of RNA $3^{\prime}$-phosphate cyclases and also proteins of the RNA cyclase-like (Rcl1) family, and discuss their documented or possible roles in different RNA metabolic reactions.
\end{abstract}

\section{INTRODUCTION}

Formation of RNAs terminating with $2^{\prime}, 3^{\prime}$-cyclic phosphate is a common phenomenon. Many endoribonucleases produce $2^{\prime}, 3^{\prime}$-cyclic phosphate-terminated RNAs as intermediates or final products of the cleavage reaction. These are proteinaceous (often referred to as cyclasing or metal-independent nucleases) or RNA-based (for example, hairpin and hammerhead ribozymes). The protein-based nucleases include bacterial and fungal ribonucleases, such as colicin D or MazF and RNases T1 or T2, as well as ribonucleases of the RNaseA/angiogenin, and inositol-requiring enzyme-1 (Ire-1; an endoribonuclease activated during unfolded protein response) and RNase L families (for review and listing of more specific references, see [1]). tRNA splicing endonucleases in both eukaryotes and archaebacteria also produce cyclic phosphates (reviewed in [2]), as do nucleases generating different tRNA fragments [3]. A more recent addition to this list is the endonuclease Las1, which is involved in processing of the ITS2 spacer in precursor ribosomal RNA [4] and the eukaryal Pichia accaciae ribotoxin PaT cleaving a specific tRNA [5]. In addition, the $2^{\prime}, 3^{\prime}$-cyclic end of the spliceosomal U6 snRNA is generated by the Usb1 $3^{\prime} \rightarrow 5^{\prime}$ exoribonuclease, which removes $3^{\prime}$-terminal uridines present in nascent $\mathrm{U} 6$ snRNA transcripts or their forms extended by specific poly(U) polymerases [6].

In all the examples listed above, terminal cyclophosphates are generated by nucleases acting on RNA molecules. However, cleavage reactions are not the only way in which RNAs bearing cyclic phosphate ends are produced. Such ends can also be generated by RNA $3^{\prime}$-terminal phosphate cyclases, i.e., enzymes catalyzing the ATP-dependent conversion of the $3^{\prime}$-phosphate to a $2^{\prime}, 3^{\prime}$-cyclic phosphodiester at the end of RNA.

\section{THE RNA 3'-TERMINAL PHOSPHATE CYCLASE: EARLY DAYS}

The RNA 3'-terminal phosphate cyclase, afterwards named RtcA, was originally identified in the early 1980s in extracts of HeLa cells and Xenopus oocyte nuclei during investigations of the mechanisms of RNA ligation in extracts of eukaryotic cells [7]. Interestingly, it became apparent at about the same time that two different types of eukaryotic RNA ligases participating in tRNA splicing or ligation of model RNA substrates use cyclic phosphates at the ligated $3^{\prime}$ end [8-16]. The two RNA ligases, originally referred to as the "yeast/plant" and "animal" enzymes, join RNA ends via the 2'-phosphomonoester, $3^{\prime}, 5^{\prime}$-phosphodiester linkage and the regular $3^{\prime}, 5^{\prime}$-phosphodiester, respectively. A similar role of cyclic ends was later demonstrated for several RNA ligases active in bacterial or archaeal cells [17-21]; reviewed in [2]. Involvement of the cyclic phosphate in RNA ligation reactions made identification of the RNA 3'-terminal phosphate cyclase particularly inter-

\section{Witold Filipowicz}

Friedrich Miescher Institute for Biomedical Research, Basel, Switzerland

Friedrich Miescher Institute for Biomedical Research, Maulberstrasse 66, 4058 Basel, Switzerland; e-mail: witold.filipowicz@fmi.ch

Received: June 1, 2016

Accepted: June 24, 2016

Key words: 2',3'-cyclic phosphate, $3^{\prime}$-phosphate cyclase, RNA cyclase, RNA ligase, RtcA RtcB, Rcl1, tRNA splicing, RNA repair

Abbreviations: UPS - unfolded protein response; Ire-1 - inositol-requiring enzyme 1; Rcl1 - RNA cyclase like 1

Acknowledgements: I thank $\mathrm{Mi} \mathrm{Li}$ and Jerry Alexandratos, NCI, Frederick for help in preparation of Figure 2, and Ronald Raines, University of Wisconsin-Madison, for making a scheme used in Figure 2 available. 
esting. Could this enzyme be responsible for the generation of proper $3^{\prime}$ termini in RNA ligation substrates? The demonstration that tRNA splicing endonucleases directly produce the $2^{\prime}, 3^{\prime}$-cyclic phosphate ends undermined this hypothesis and - as discussed below - the biological function of RtcA enzymes is still not well understood.

The cyclisation of the 3 'terminal phosphate by RtcA occurs in three steps:

(i) Enzyme + ATP $\rightarrow$ Enzyme-AMP $+\mathrm{PP}_{\text {i }}$

(ii) RNA-N ${ }^{3^{\prime}} \mathrm{p}+$ Enzyme-AMP $\rightarrow$ RNA-N $\mathrm{N}^{3^{\prime}} \mathrm{pp}^{5^{\prime}} \mathrm{A}+$ Enzyme

\section{(iii) $\mathrm{RNA}-\mathrm{N}^{3^{\prime}} \mathrm{pp}^{5^{\prime}} \mathrm{A} \rightarrow \mathrm{RNA}-\mathrm{N}>\mathrm{p}+\mathrm{AMP}$}

Initial support for step (i) came from the identification of the covalent cyclase-AMP intermediate and the activity of 3'-phosphorylated RNA but not 3'-OH RNA in releasing AMP from the preformed cyclase-AMP [22-25]. Step (ii) was supported by accumulation of RNA-N3'pp5'A molecules when the $3^{\prime}$-terminal ribose of the substrate is replaced by the $2^{\prime}$-deoxy- or $2^{\prime}$-O-methyl-ribose [22]. In step (iii), the adjacent $2^{\prime}-\mathrm{OH}$ attacks the activated $3^{\prime}$-phosphate, which forms the cyclic phosphate and releases AMP.

Early biochemical studies of the human cyclase, partially or highly ( $6^{\prime} 000$-fold) purified from extracts of HeLa cells, revealed that the enzyme acts as a monomer of $M_{r} \sim 40^{\prime} 000$. The $\mathrm{pH}$ optimum of cyclisation of RNA substrates was between 8.0 and 9.0, and $\mathrm{Mg}^{++}$was the preferred divalent cation. ATP serves as a preferred co-factor in nucleotidylation and cyclisation assays, with other nucleoside triphosphates being much less active [22$24,26,27]$. More importantly, purification of the human cyclase enabled cloning of its cDNA [24], which in turn allowed the identification of RtcA proteins in other species and made purified recombinant proteins available for biochemical and structural studies.

Analysis of the human cDNA revealed that genes encoding RtcA are highly conserved among eukaryotes, eubacteria and archaea. The encoded proteins represent a novel family with no readily apparent features in common with proteins of known function. The properties of purified endogenous and recombinant human cyclases were found to be very similar. The gene was found to be broadly expressed in various human cell lines and tissues, with highest expression in skeletal muscle [24]. Analysis of recombinant purified RtcA from Escherichia coli revealed that the properties and substrate specificities of human and bacterial enzymes are similar and that the reaction proceeds via formation of a covalent RtcA-AMP intermediate. The only apparent differences include the ability of $\mathrm{Mn}^{++}$ions to replace $\mathrm{Mg}^{++}$in reactions catalyzed by the $E$. coli enzyme, and that GTP is a relatively more efficient cofactor with the E. coli than with the human enzyme [25]. Interestingly, purified RtcA from the archaeon Pyrococcus furiosus appears to use GTP 10 times more effectively than ATP in the cyclisation reaction [28].
Identification of the $r t c A$ gene in $E$. coli offered the first opportunity to study its function. Regrettably, the rtcA gene turned out not to be essential for growth [25]. rtcA forms part of an operon containing two additional ORFs. The ORF positioned immediately upstream of $r t c A$, named $r t c B$, encodes a protein that is also highly evolutionarily conserved and, as demonstrated later, has RNA ligase activity $[16,18,20,21]$; reviewed in [2]. The third ORF, $r t c R$, which is transcribed in the opposite direction, encodes a transcriptional activator controlling expression of $r t c A$ and $r t c B$ in a $\sigma^{54}$-dependent manner [25]. The dispensability of the $r t c A$ operon is not that surprising given that nearly all known $\sigma^{54}$-controlled operons are not essential for the growth of bacteria under standard conditions and are induced as part of different adaptive reactions, including responses to different types of stress [29]. To understand the biological functions of RtcA and RtcB, it will be important to identify conditions or effectors leading to the induction of the operon.

\section{STRUCTURAL STUDIES AND REFINEMENT OF THE MECHANISTIC ASPECTS OF THE ENZYME}

The cyclase structure was first solved by the laboratory of Alex Wlodawer, to whom this article is dedicated [30]. The $2.1 \AA$ resolution crystal structure of the E. coli protein showed the cyclase molecule to consist of two domains (Fig. 1A). The larger domain contains three repeats of a folding unit comprising two parallel a helices and a four-stranded $\beta$ sheet, the fold previously identified in the translation initiation factor 3 (IF3). The large domain is also similar to one of the two domains of 5-enolpyruvylshikimate-3-phosphate synthase (EPSPS) and UDP-N-acetylglucosamine enolpyruvyl transferase (MurA). These two enzymes are not involved in RNA metabolism but, like cyclase, bind multiple phosphates during their catalytic cycles. The smaller domain of the cyclase comprises similar secondary structure elements with a four-stranded $\beta$ sheet and two parallel helices, but their connection topology is different and resembles that observed in human thioredoxin and some other proteins [30]. The structure provided a first indication of the catalytic region of the enzyme, surrounding the conserved and absolutely essential His309. Mass spectrometry had shown earlier that the AMP residue in the covalent RtcA-AMP intermediate of the cyclisation is linked via a phosphoramidate $(\mathrm{P}-\mathrm{N})$ bond to the side chain of His309 [31].

There followed a series of very elegant experiments performed in Shuman's laboratory that determined the structure-activity relationships of the enzyme and the structures of different RtcA complexes and the covalent RtcA-AMP intermediate [32-34] (Fig. 1B and C). The structure-guided mutagenesis of human RtcA defined seven conserved residues as essential for the adenylylation and cyclisation reactions [32]. These include His320 (equivalent to His309 in E. coli RtcA) and three conserved arginines, Arg21, Arg40, and Arg43; these residues together with several others coordinate binding of the citrate ion, likely a mimetic of ATP phosphates and/or RNA 3'-phos- 

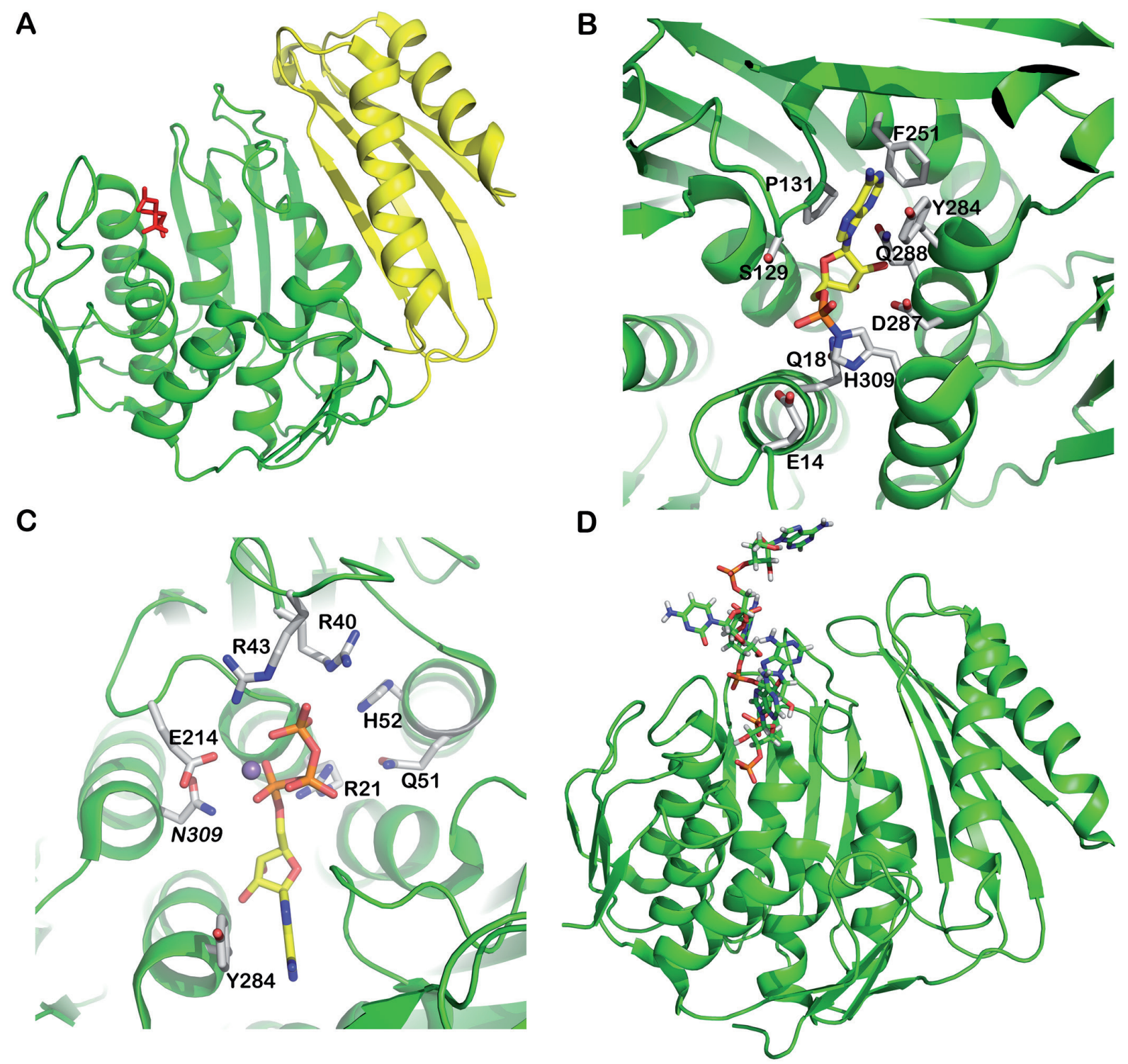

Figure 1. Structures of RtcA, RtcA-AMP intermediate and complexes with ATP and RNA. (A) Ribbon representation of the $E$. coli RtcA with a large domain shown in green and small domain in yellow (PDB 1qmh). The citrate molecule bound to the protein is shown in red stick representation. (B) Structure of the covalent RtcA-AMP intermediate (PDB 3kgd). Adenylate (shown in sticks) is linked via a phosphoamide bond to the His309 Ne atom. Selected amino acid side chains are shown. (C) Structure of the E. coli RtcA in a complex with ATP and $\mathrm{Mn}^{++}$cation (PDB 3tux). Selected amino acid side chains are shown. N309 represents mutation of His 309 introduced to prevent formation of the covalent adenylylated intermediate. (D) Structure of RtcA from the archaeon P. horikoshi bound to substrate RNA (pentanucleotide ACAAA ${ }^{3}$; depicted as sticks) (PDB 4o8j).

phate end, in the apoRtcA structure ([30]; Fig. 1A). The arginines were found to be indeed essential, both for the adenylylation step and for the adenylylation-independent interaction with the 3'-phosphate-terminated RNA. No stable binary complex was observed with the 3'-OH-terminated RNA, which indicated an important role for the $3^{\prime}$-phosphate in substrate RNA binding [32].

Structural analysis of the covalent RtcA-AMP intermediate of the E. coli enzyme [33] demonstrated unambiguously that AMP is linked via a P-N bond to the Ne atom of His309 (Fig. 1B). Analysis of the adenylate-binding pocket also helped to explain the nucleotide specificity of the enzyme.

Chakravarty et al. [34] determined the structures of different RtcA complexes with ATP and AMP, with and without metal ions. This work revealed a network of contacts between the adenosine moiety and three ATP phosphates, including coordination of $\beta$ and $\gamma$ phosphates by arginines 21, 40, and 43 as well as Gln51and His52 (Fig. 1C). Glu14 was found to be involved in metal binding but, interestingly, only the first step of the cyclisation reaction, the adenylylation of the enzyme, was found to be metal-dependent. The structure of the RtcA-AMP (non-covalent) complex was proposed to be a mimetic of the post-cyclisation product complex (Step iii of the reaction).

These findings were nicely complemented by structural analysis of the archaeon Pyrococcus horihoshi RtcA complexed with 3'-phosphate-terminated RNA, performed in Raines' laboratory [35] (Fig. 1D and Fig. 2). The 2.1 structure revealed allocation of a large proportion of hy- 
$5^{\prime} \mathrm{A}_{1} . \mathrm{C}_{2} . \mathrm{A}_{3} . \mathrm{A}_{4} . \mathrm{A}_{5} 3^{\prime}-\mathrm{p}$

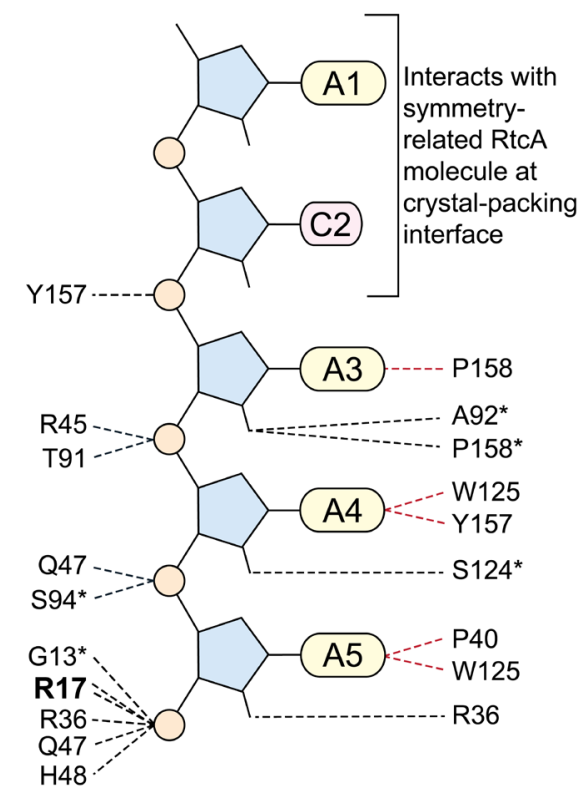

Figure 2. A scheme depicting the archaeon P. horikoshi RtcA hydrogen bonding (dashed black lines) and van der Waals interactions (dashed magenta lines) with the bound RNA (pentanucleotide $\mathrm{ACAAA}^{3} \mathrm{p}$ ). Asterisks denote backbone interactions. Note that numbering of $P$. horikoshi RtcA differs from that of the $E$. coli protein. The scheme is reproduced, with permission of RNA, from reference [35].

drogen bonds (involving five conserved amino acids, including counterparts of Arg21 and Arg40, and also those of Gln51 and His52) to the non-bridging oxygens of the terminal phosphate, which prejudices RtcA against $3^{\prime}-\mathrm{OH}$ termini. The data also showed that RtcA contains three nucleotide-binding sites, consistent with the trinucleotide being the minimum size for RtcA substrates [23,24]. In turn, hydrogen bonding with the ribose 2 '-OH of the three terminal nucleotides explains the strong preference ( 500-fold; [24,25]) for RNA over DNA substrates (Fig. 2). Inspection of RtcA-ATP and RtcA-RNA complexes indicated a strong overlap between regions binding the ATP phosphates and the 3'-phosphorylated end of RNA substrate [34,35]. Moreover, comparison of the structures of complexes representing different steps of cyclisation with that of the apoenzyme indicated that the reaction progress is accompanied by conformational switches of the protein. The data led also to a detailed proposal of the mechanism of the cyclisation reaction [33-35].

Early experiments indicated that 3'-phosphorylated RNA is a highly preferred substrate of RtcA. RNA terminated with $3^{\prime}$-phosphorylated 2'-deoxy- or 2'-O-methyl-ribose was converted to RNA- $\mathrm{dN}^{3^{\prime}} \mathrm{pp}^{5^{\prime}} \mathrm{A}$ or RNA- $\left(2^{\prime}-\mathrm{O}-\right.$ methyl) $\mathrm{N}^{3^{\prime}} \mathrm{pp}^{5^{\prime}} \mathrm{A}$ products with a low yield [22], while the 3 '-phosphorylated oligodeoxynucleotides were at least $\sim 500$-fold less active than RNA in a comparison of different substrates in a competition/inhibition assay or in the ability to release AMP from the preformed RtcA-AMP complex [24,25]. More recently, Das and Shuman [36] demonstrated that RtcA cyclizes the 2'-phosphorylated RNA with a high yield, although at a rate five orders of magnitude slower than the 3 '-phosphate cyclisation. This very slow rate is a likely explanation of why the 2 '-phosphorylated RNAs were previously reported to be inactive as substrates [7,23]. Das and Shuman [36] proposed that RtcA under some conditions might have an end-healing activity converting the $2^{\prime}$-phosphate end (e.g., resulting from hydrolysis of cyclic phosphate to the $2^{\prime}$-phosphate product by cellular $2^{\prime}, 3^{\prime}$-cyclic nucleotide $3^{\prime}$-phosphodiesterases; reviewed in $[37,38])$ to the $2^{\prime}, 3^{\prime}$-cyclic. With the exception of the tRNA splicing ligase active in fungi and plants, the $2^{\prime}$-phosphate RNA cannot function in RNA ligation; its conversion to $2^{\prime}, 3^{\prime}$-cyclic phosphate would expose the RNA to other types of RNA ligases.

Chakravarty and Shuman [39] extended the known substrate specificity of RtcA even further. They demonstrated that at the slow rate the E. coli RtcA can convert, in a reaction involving an RctA-AMP covalent intermediate, the $5^{\prime}$-phosphates in RNA and DNA into $\mathrm{A}^{5^{\prime}} \mathrm{pp}^{5^{\prime}} \mathrm{N}$ structures. This modification optimally occurs at $\mathrm{pH}$ of 5.5-6.0, in contrast with the $3^{\prime}$-phosphate cyclisation reaction, which has optimum at $\mathrm{pH}$ 8.0-9.0 and very low activity at $\mathrm{pH} 5.5 / 6.0$; [26]. In the view of the rather strict requirements for acceptance of the RNA phosphomonoester 3'end in the catalytic pocket of RtcA, including recognition of the $3^{\prime}$-phosphate and three terminal nucleotides with the ribose 2 '-hydroxyls ([35]; Fig. 2), the efficient use of the $5^{\prime}$-phosphorylated RNA or DNAs as substrate is rather surprising. The crystal structures of RtcA complexes with 5'p RNA and DNA will be of great interest.

The aforementioned $\mathrm{A}^{5^{\prime}} \mathrm{pp}^{5^{\prime}} \mathrm{N}$-terminated RtcA products resemble intermediates formed in many RNA or DNA ligation reactions (reviewed in $[2,40]$ ). Although RtcA is incapable of phosphodiester synthesis (i.e., ligation) following adenylation of the $5^{\prime}$-terminal phosphate [39], formation of activated $\mathrm{A}^{5^{\prime}} \mathrm{pp}^{5^{\prime}} \mathrm{N}$-terminated products by both RNA/DNA ligases and RtcA makes these classes of enzymes partially overlapping in their repertory of catalytic reactions. In this context it is important to note that some RNA ligases (e.g., phage T4 RNA ligase 1 or RNA ligase from the archaeon Methanobacterium thermoautotrophicum; [41,42]), physiologically operating via formation of $\mathrm{A}^{5^{\prime}} \mathrm{pp}^{5^{\prime}} \mathrm{N}$-terminated intermediates, can convert the $3^{\prime}$-phosphomonoester to cyclic phosphate by an RtcA-like mechanism when presented with RNA substrates devoid of 5 '-phosphate but containing the 3 '-phosphate end. Interestingly, RtcB ligase, which ligates 3'-phosphorylated and 5'-OH termini via formation of the RNA-N ${ }^{3} \mathrm{pp}^{5^{\prime}} \mathrm{G}$ intermediate, can also produce $2^{\prime}, 3^{\prime}$-cyclic ends when the $5^{\prime}-\mathrm{OH}$ donor end is not available or blocked by $5^{\prime}$ phosphorylation [43]. Note that RtcB ligation proceeds via guanylylation and not adenylylation of the protein and the transfer of GMP to the 3'-terminal phosphate $[21,44]$. Despite the aforementioned mechanistic similarities between RNA or DNA ligases and RtcA, the ligase and cyclase protein families lack any appreciable structural homology.

\section{SEARCHING FOR THE CYCLASE FUNCTION}

The biological role of RNA 3'-terminal phosphate cyclases is not well understood. Wide conservation of the 
enzyme in all life forms suggests that its activity is important. The initial suggestion [45] that the enzyme might be involved in the generation of the cyclic phosphate 3' end of U6 snRNA should be disregarded, since another enzyme, exoribonuclease Usb1, has been shown to perform this function [6]. Similarly, the suggested role of RtcA in the generation or maintenance of cyclic ends in tRNA splicing intermediates or other ligation substrates is not very likely. First, endoribonucleases involved in excision of introns from pre-tRNAs and in the unorthodox RNA ligase-dependent mRNA splicing during unfolded protein response (UPR) directly produce the cyclic phosphate termini ([1,2]; see also above). Second, RNA ligases involved in RNA ends joining were shown to also use either 3'-phosphomonoesters in the case of the E. coli RtcB-type ligases [21,44] or 2'-phospho-monoesters in the case of the yeast/plant-type tRNA splicing ligases producing the 2'-phosphomonoester, 3',5'-phosphodiester linkage $[13,46,47]$. These monoester-terminated 3 ' ends represent first step intermediates of the reactions initiated with cyclophosphate end substrates (reviewed in [2]). Nevertheless, the cyclic end (re)generation idea should not be entirely discarded. As already discussed above [36], RtcA could possibly heal (i.e., cyclize) the 2 '-phosphorylated end and make it compatible for ligation by RtcB or other ligases. Moreover, the preferences of RNA ligases in vivo are not known. In this context, it is important to note that ligation of the substrate with the preformed cyclic end proceeds in the HeLa cell extract with a large kinetic advantage over that with a $3^{\prime}$-phosphorylated end; utilization of the latter appears to follow its conversion to cyclophosphate by RtcB present in the extract [7]. Perkins et al. [15] also reported that partially purified RNA ligase from HeLa cells appears not to utilize $3^{\prime}$-phosphomonoester substrates unless their ends are converted to the $2^{\prime}, 3^{\prime}$-cyclics.

When speculating about RtcA function(s), one should also consider its potential role in processes not related to RNA ligation. For example, cyclisation of the 3 '-terminal monophosphate could protect it against action of cellular phosphatases. Moreover, demonstration that RtcA can also convert nucleic acid 5'-terminal phosphates to $\mathrm{A}^{5^{\prime}} \mathrm{pp}^{5^{\prime} \mathrm{N}}$ structures opens still other possibilities. Such structures could protect the ends from exonucleolytic degradation or render modified RNA or DNA active as donors in ligation reactions [39].

It is significant that in eubacterial and archaebacterial genomes, RtcA is very frequently part of operons encoding also other proteins involved in RNA transactions. For example, in a number of prokaryota, the RtcA gene is adjacent to the gene encoding archease, a stimulatory factor for the RNA ligase RtcB [48,49]. As discussed in this article, in E. coli and some other bacteria, RtcA is co-expressed with the RNA ligase RtcB $[25,36]$. In still another set of bacterial taxa, in addition to RtcB and RtcR (transcriptional activator of the operon), the "cyclase" operon also encodes Ro, the RNA binding protein implicated in small RNA quality control and stress-induced ribosomal RNA metabolism (for discussion, see [36,50]). Interestingly, as exemplified by the situation in Salmonella enterica serovar Typhimurium, the operon also encodes two small non-coding RNAs and two components of the DinJ-YafQ toxin-antitoxin system, known to control a process of mRNA translation $[36,50]$. These observations prompted Das and Shuman [36] to speculate that ribotoxic damage produced by YafQ endoribonuclease may be modulated and/or repaired by the Ro, RtcA and RtcB proteins. Clearly, identifying signals that control expression of this and other $r t c A$-containing operons, should help in understanding the biological function of RtcA in bacteria. Notably, bacterial and fungal genomes encode many ribotoxins cleaving tRNAs or mRNAs $[1,51]$ and it is likely that RNA ligases, possibly with assistance of cyclases and other factors acting on RNA, are involved in a regulated repair of the damage. The concept of RNA repair has been championed by Stewart Shuman and his collaborators (see, for example $[36,52,53]$ ). Multitude of proven or putative RNA ligases expressed in some organisms (e.g., fifteen in the amoebo-flagellate protozoan Naegleria gruberi [54] and six in the bacterium Myxococcus xantus [55]) offers support to this notion.

Two recent screens, one proteomic and another aimed at identifying genes regulating axon regeneration, quite unexpectedly identified RtcA and its "companions" in prokaryotic operons as factors implicated in neuronal function. Kanai et al. [56] identified RtcA and components of the RtcB tRNA splicing ligase complex as proteins interacting with kinesin-associated RNA transport granules in mouse brain extracts. A total of 42 protein components of granules have been identified, with about half of them having a role in RNA metabolism or transport and mRNA translation. Some proteins investigated in more detail localized to granules in dendrites. A functional role for Rtc $A$ and RtcB in the transport granules remains to be investigated. While screening for genes affecting axon regeneration in Drosophila, Song et al. [57] identified RtcA as an inhibitor of axon regeneration and identified archease, an activator of RtcB, as a pro-regeneration factor. An inhibitory role RtcA in axon branching and regeneration was confirmed in rodent neurons. In an attempt to provide mechanistic understanding of the phenomenon, the authors found that RtcA and archease target splicing of the X-box binding protein 1 (Xbp1) mRNA, acting as its inhibitor and activator, respectively. Xbp-1 mRNA splicing is activated during UPR and it follows the unorthodox cytoplasmic pathway involving (in animals) RtcB and archease (reviewed in [58]). Somewhat contradictory results were reported for the Caenorhabditis elegans. Kosmaczewski et al. [59] demonstrated that archease and ligase RtcB act in neurons to inhibit, rather than stimulate axon regeneration after nerve injury. Surprisingly, they found that the function of RtcB and archease is independent of their role in tRNA or Xbp1 mRNA splicing, arguing for still additional roles of these enzymes in RNA metabolism in neurons; the role of RtcA in axon regeneration in C. elegans has not been investigated. Taken together, the papers discussed above point to the role of RtcA and $\mathrm{RtcB} /$ archease in RNA processing in neurons. Future experimentation will no doubt shed more light on the generality and mechanism of their function. 


\section{Rcl1: A FAMILY OF RNA 3'TERMINAL PHOSPHATE CYCLASE-LIKE PROTEINS}

Inspection of different genomes for sequences with similarity to the human and E. coli RtcA, the first molecularly characterized enzymes with cyclase activity, allowed proteins showing similarity to be divided into two subfamilies referred to originally as class I and class II [24]. Class I are catalytically active cyclases, all with a conserved histidine equivalent to His309 of the E. coli enzyme; this residue undergoes covalent adenylylation. The class I genes are conserved in eukaryotes, bacteria and archaea. The class II members, expressed only in eukaryotes, were subsequently referred to as the RNA-3'-terminal-phosphate-cyclase-like (Rcl) proteins. The Rtc and Rcl families show a high sequence similarity. For example, human RtcA and Rcl1 proteins are 34\% identical and 43\% similar.

Analysis of the Rcl1p protein from Saccharomyces cerevisiae found no cyclase activity, which is consistent with the absence of a histidine equivalent to the E. coli His309 in this molecule and its counterparts in other eukaryotes. This is further supported by structural analysis of the yeast Rcl1p. The $2.6 \AA$ structure of the protein revealed a tertiary fold highly homologous to the E. coli cyclase RtcA [60]. In Rcl1p, His309 is replaced by arginine, which is unlikely to function as a nucleofile in the nucleotydyl transfer. Moreover, Rcl1p lacks the conserved residues of RtcA that are involved in metal coordination as well as adenine nucleotide and RNA binding. The crystal structure of Rcl1p revealed a tartrate anion in the position of the citrate or sulfate anions found in crystal structures of RtcA [30,33]. Mutations of 14 amino acids surrounding the binding site of the tartrate ion, a potential "mimic" of RNA bound at or near the putative catalytic region, yielded proteins able to rescue yeast growth at all temperatures tested [60].

Although not encoding an active cyclase, the RCL1 gene was found to be essential for the growth of S. cerevisiae. Depletion of Rcl1p impairs precursor ribosomal RNA (pre-rRNA) processing at sites $\mathrm{A} 0, \mathrm{~A} 1$ and $\mathrm{A} 2$ and leads to a strong decrease in mature $18 \mathrm{~S}$ rRNA and $40 \mathrm{~S}$ ribosomal subunit levels [61,62] (for review of pre-rRNA processing, see [63]). Consistently, Rcl1p is localized in the nucleolus, the site of ribosome biogenesis. Rcl1p physically interacts with Bms1p, an essential GTPase also required for early cleavage of the pre-rRNA at sites $\mathrm{A}_{0^{\prime}} \mathrm{A}_{1}$ and $\mathrm{A}_{2}$ and the production of $18 \mathrm{~S}$ rRNA; both Rcllp and Bms1p associate with U3 snoRNP, a particle orchestrating early pre-rRNA processing events during $40 \mathrm{~S}$ subunit formation $[62,64,65]$. Depletion of Bms1p prevents incorporation of Rcl1p into pre-ribosomes and Bms1p is required for the nuclear import of Rcl1p, consistent with the nuclear localization signal present in Bms1p $[62,65,66]$.

Similarity of Rcl1 to the enzymatically active cyclases, and structural resemblance of large domains of RtcA and Rcl1 proteins to the domains of the two related enzymes EPSPS and MurA involved in peptidoglycan and chorismate synthesis [30], raised a question whether also Rcl1 could function as an enzyme. For example, Rcl1 might represent an endoribonuclease responsible for one of the early cleavages of pre-rRNA [61]. Indeed, Karbstein's laboratory [67] reported that Rcl1p might function as an endonuclease catalyzing cleavage at the $\mathrm{A} 2$ site, resulting in separation of rRNA destined for small and large ribosomal subunits. However, other results argue against this possibility. First, the structure-guided substitutions, clustered or individual, in the Rcllp region superimposing with the catalytic pocket of the E. coli RtcA did not cause detectable growth defects ([60]; see also above). Secondly, one of the Rcl1p mutants, RDK $\rightarrow$ AAA, which was thought to offer strong support for a role of the protein in pre-rRNA recognition and/or cleavage, appears rather to compromise the Rcl1p-Bms1p interaction known to be essential for pre-rRNA processing $[66,68]$. Finally, strong evidence exists that another protein, the PIN domain endonuclease Utp24, is responsible for A2 site cleavage in yeast [68]. Clearly, further work is required to establish whether Rcl1 acts, possibly redundantly with Utp24, as an endonuclease or rather plays another more structural role in pre-rRNA processing and $40 \mathrm{~S}$ ribosome biogenesis.

\section{REFERENCES}

1. Yang W (2011) Nucleases: diversity of structure, function and mechanism. Q Rev Biophys 44: 1-93

2. Popow J, Schleiffer A, Martinez J (2012) Diversity and roles of ( $t$ )RNA ligases. Cell Mol Life Sci 69: 2657-2670

3. Honda S, Morichika K, Kirino Y (2016) Selective amplification and sequencing of cyclic phosphate-containing RNAs by the cP-RNA-seq method. Nat Protoc 11: 476-489

4. Gasse L, Flemming D, Hurt E (2015) Coordinated Ribosomal ITS2 RNA Processing by the Las1 Complex Integrating Endonuclease, Polynucleotide Kinase, and Exonuclease Activities. Mol Cell 60: 808815

5. Chakravarty AK, Smith P, Jalan R, Shuman S (2014) Structure, mechanism, and specificity of a eukaryal tRNA restriction enzyme involved in self-nonself discrimination. Cell Rep 7: 339-347

6. Mroczek S, Dziembowski A (2013) U6 RNA biogenesis and disease association. Wiley Interdiscip Rev RNA 4: 581-592

7. Filipowicz W, Konarska M, Gross HJ, Shatkin AJ (1983) RNA 3'-terminal phosphate cyclase activity and RNA ligation in HeLa cell extract. Nucleic Acids Res 11: 1405-1418

8. Konarska M, Filipowicz W, Domdey H, Gross HJ (1981) Formation of a 2'-phosphomonoester, 3', 5' -phosphodiester linkage by a novel RNA ligase in wheat germ. Nature 293: 112-116

9. Konarska M, Filipowicz W, Gross HJ (1982) RNA ligation via 2'-phosphomonoester, 3',5'-phosphodiester linkage: requirement of 2',3'-cyclic phosphate termini and involvement of a $5^{\prime}$-hydroxyl polynucleotide kinase. Proc Natl Acad Sci USA 79: 1474-1478

10. Furneaux H, Pick L, Hurwitz J (1983) Isolation and characterization of RNA ligase from wheat germ. Proc Natl Acad Sci USA 80: 3933-3937

11. Greer CL, Peebles CL, Gegenheimer P, Abelson J (1983) Mechanism of action of a yeast RNA ligase in tRNA splicing. Cell 32: 537-546

12. Filipowicz W, Shatkin AJ (1983) Origin of splice junction phosphate in tRNAs processed by HeLa cell extract. Cell 32: 547-557

13. Schwartz RC, Greer CL, Gegenheimer P, Abelson J (1983) Enzymatic mechanism of an RNA ligase from wheat germ. J Biol Chem 258: 83748383

14. Gegenheimer P, Gabius HJ, Peebles CL, Abelson J (1983) An RNA ligase from wheat germ which participates in transfer RNA splicing in vitro. J Biol Chem 258: 8365-8373 
15. Perkins KK, Furneaux H, Hurwitz J (1985) Isolation and characterization of an RNA ligase from HeLa cells. Proc Natl Acad Sci USA 82: 684-688

16. Popow J, Englert M, Weitzer S, Schleiffer A, Mierzwa B, Mechtler K, Trowitzsch S, Will CL, Lührmann R, Söll D et al (2011) HSPC117 is the essential subunit of a human tRNA splicing ligase complex. Science 331: 760-764

17. Arn EA, Abelson JN (1996) The 2'-5' RNA ligase of Escherichia coli. Purification, cloning, and genomic disruption. J Biol Chem 271: 3114531153

18. Tanaka N, Shuman S (2011) RtcB is the RNA ligase component of an Escherichia coli RNA repair operon. J Biol Chem 286: 7727-7731

19. Tanaka N, Meineke B, Shuman S (2011) RtcB, a novel RNA ligase, can catalyze tRNA splicing and HAC1 mRNA splicing in vivo. J Biol Chem 286: 30253-30257

20. Englert M, Sheppard K, Aslanian A, Yates JR III., Söll D (2011) Archaeal 3'-phosphate RNA splicing ligase characterization identifies the missing component in tRNA maturation. Proc Natl Acad Sci USA 108: 1290-1295

21. Desai KK, Raines RT (2012) tRNA ligase catalyzes the GTP-dependent ligation of RNA with $3^{\prime}$-phosphate and 5'-hydroxyl termini. Biochemistry 51: 1333-1335

22. Filipowicz W, Strugala K, Konarska M, Shatkin AJ (1985) Cyclization of RNA 3'-terminal phosphate by cyclase from HeLa cells proceeds via formation of $\mathrm{N}\left(3^{\prime}\right) \mathrm{pp}\left(5^{\prime}\right) \mathrm{A}$ activated intermediate. Proc Natl Acad Sci USA 82: 1316-1320

23. Reinberg D, Arenas J, Hurwitz J (1985) The enzymatic conversion of 3'-phosphate terminated RNA chains to 2',3'-cyclic phosphate derivatives. J Biol Chem 260: 6088-6097

24. Genschik P, Billy E, Swianiewicz M, Filipowicz W (1997) The human RNA 3'-terminal phosphate cyclase is a member of a new family of proteins conserved in Eucarya, Bacteria and Archaea. EMBO J 16: 2955-2967

25. Genschik P, Drabikowski K, Filipowicz W (1998) Characterization of the Escherichia coli RNA 3'-terminal phosphate cyclase and its sigma54-regulated operon. J Biol Chem 273: 25516-25526

26. Vicente O, Filipowicz W (1988) Purification of RNA 3'-terminal phosphate cyclase from HeLa cells. Covalent modification of the enzyme with different nucleotides Eur J Biochem 176: 431-439

27. Filipowicz W, Vicente O (1990) RNA 3'-terminal phosphate cyclase from HeLa cells. Methods Enzymol 181: 499-510

28. Sato A, Soga T, Igarashi K, Takesue K, Tomita M, Kanai A (2011) GTP-dependent RNA 3'-terminal phosphate cyclase from the hyperthermophilic archaeon Pyrococcus furiosus. Genes Cells 16: 1190-1199

29. Wigneshweraraj $S$ et al (2008) Modus operandi of the bacterial RNA polymerase containing the sigma54 promoter-specificity factor. Mol Microbiol 8: 538-546

30. Palm GJ, Billy E, Filipowicz W, Wlodawer A (2000) Crystal structure of RNA3'-terminal phosphate cyclase, a ubiquitous enzyme with unusual topology. Structure 8:13-23

31. Billy E, Hess D, Hofsteenge J, Filipowicz W (1999) Characterization of the adenylation site in the RNA 3'-terminal phosphate cyclase from Escherichia coli. J Biol Chem 274: 34955-34960

32. Tanaka N, Shuman S (2009) Structure-activity relationships in human RNA 3'-phosphate cyclase. RNA 15: 1865-1874

33. Tanaka N, Smith P, Shuman S (2010) Structure of the RNA 3'-phosphate cyclase-adenylate intermediate illuminates nucleotide specificity and covalent nucleotidyl transfer. Structure 18: 449-457

34. Chakravarty AK, Smith P, Shuman S (2011) Structures of RNA 3'-phosphate cyclase bound to ATP reveal the mechanism of nucleotidyl transfer and metal-assisted catalysis. Proc Natl Acad Sci 108: 21034-21039

35. Desai KK, Bingman CA, Cheng CL, Phillips GN Jr, Raines RT (2014) Structure of RNA 3'-phosphate cyclase bound to substrate RNA. RNA 20: $1560-1566$

36. Das U, Shuman S (2013) 2'-Phosphate cyclase activity of RtcA: a potential rationale for the operon organization of RtcA with an RNA repair ligase RtcB in Escherichia coli and other bacterial taxa. RNA 19: 13551362

37. Remus BS, Jacewicz A, Shuman S (2014) Structure and mechanism of E. coli RNA 2', 3'-cyclic phosphodiesterase. RNA 20: 1697-705

38. Myllykoski M, Seidel L, Muruganandam G, Raasakka A, Torda AE, Kursula P (2015) Structural and functional evolution of $2^{\prime}, 3^{\prime}$-cyclic nucleotide 3'-phosphodiesterase. Brain Res, in press, doi:10.1016

39. Chakravarty AK, Shuman S (2011) RNA 3'-phosphate cyclase (RtcA) catalyzes ligase-like adenylylation of DNA and RNA 5'-monophosphate ends. J Biol Chem 286: 4117-4122

40. Shuman S (2009) DNA ligases: progress and prospects. J Biol Chem 284: $17365-17369$

41. Hinton DM, Brennan CA, Gumport RI (1982) The preparative synthesis of oligodeoxyribonucleotides using RNA ligase. Nucleic Acids Res 10: 1877-1894

42. Zhelkovsky AM, McReynolds LA (2014) Polynucleotide 3'-terminal phosphate modifications by RNA and DNA ligases. J Biol Chem 289: 33608-33616

43. Tanaka N, Chakravarty AK, Maughan B, Shuman S (2011) Novel mechanism of RNA repair by RtcB via sequential $2^{\prime}, 3^{\prime}$-cyclic phosphodiesterase and 3'-Phosphate/5'-hydroxyl ligation reactions. J Biol Chem 286: 43134-43143

44. Chakravarty AK, Subbotin R, Chait BT, Shuman S (2012) RNA ligase RtcB splices 3'-phosphate and 5'-OH ends via covalent RtcB-(histidinyl)-GMP andpolynucleotide- $\left(3^{\prime}\right) \mathrm{pp}\left(5^{\prime}\right) \mathrm{G}$ intermediates. Proc Natl Acad Sci USA 109: 6072-6077

45. Filipowicz W, Billy E, Drabikowski K, Genschik P (1998) Cyclases of the 3 '-terminal phosphate in RNA: a new family of RNA processing enzymes conserved in eucarya, bacteria and archaea. Acta Biochim Pol 45: 895-906

46. Phizicky EM, Schwartz RC, Abelson J (1986) Saccharomyces cerevisiae tRNA ligase. Purification of the protein and isolation of the structural gene. J Biol Chem 261: 2978-2986

47. Remus BS, Shuman S (2013) A kinetic framework for tRNA ligase and enforcement of a 2'-phosphate requirement for ligation highlights the design logic of an RNA repair machine. RNA 19: 659-669

48. Popow J, Jurkin J, Schleiffer A, Martinez J (2014) Analysis of orthologous groups reveals archease and DDX1 as tRNA splicing factors. Nature 511: 104-107

49. Desai KK, Cheng CL, Bingman CA, Phillips GN Jr, Raines RT (2014) A tRNA splicing operon: archease endows RtcB with dual GTP/ATP cofactor specificity and accelerates RNA ligation. Nucleic Acids Res 42: 3931-3942

50. Chen X, Taylor DW, Fowler CC, Galan JE, Wang HW, Wolin S (2013) An RNA degradation machine sculpted by Ro autoantigen and noncoding RNA. Cell 153: 166-177

51. Cook GM, Robson JR, Frampton RA, McKenzie J, Przybilski R, Fineran PC, Arcus VL (2013) Ribonucleases in bacterial toxin-antitoxin systems. Biochim Biophys Acta 1829: 523-531

52. Nandakumar J, Schwer B, Schaffrath R, Shuman S (2008) RNA repair: an antidote to cytotoxic eukaryal RNA damage. Mol Cell 31: 278-286

53. Meineke B, Shuman S (2012) Determinants of the cytotoxicity of PrrC anticodon nuclease and its amelioration by tRNA repair. RNA 18: 145154

54. Unciuleac MC, Shuman S (2015) Characterization of a novel eukaryal nick-sealing RNA ligase from Naegleria gruberi. RNA 21: 824-832

55. Maughan WP, Shuman S (2015) Characterization of 3'-Phosphate RNA Ligase Paralogs RtcB1, RtcB2, and RtcB3 from Myxococcus xanthus Highlights DNA and RNA 5'-Phosphate Capping Activity of RtcB3. J Bacteriol 197: 3616-3624

56. Kanai Y, Dohmae N, Hirokawa N (2004) Kinesin transports RNA: isolation and characterization of an RNA-transporting granule. Neuron 43: $513-525$

57. Song $\mathrm{Y}$, Sretavan D, Salegio EA, Berg J, Huang X, Cheng T, Xiong X, Meltzer S, Han C, Nguyen TT, Bresnahan JC, Beattie MS, Jan LY, Jan YN (2015) Regulation of axon regeneration by the RNA repair and splicing pathway. Nat Neurosci 18: 817-825 
58. Filipowicz W (2014) Making ends meet: a role of RNA ligase RTCB in unfolded protein response. EMBO J 33: 2887-2889

59. Kosmaczewski SG, Han SM, Han B, Irving Meyer B, Baig HS, Athar W, Lin-Moore AT, Koelle MR, Hammarlund M (2015) RNA ligation in neurons by RtcB inhibits axon regeneration. Proc Natl Acad Sci USA 112: 8451-8456

60. Tanaka N, Smith P, Shuman S (2011) Crystal structure of Rcl1, an essential component of the eukaryal pre-rRNA processosome implicated in 18s rRNA biogenesis. RNA 17: 595-602

61. Billy E, Wegierski T, Nasr F, Filipowicz W (2000) Rcl1p, the yeast protein similar to the RNA 3'-phosphate cyclase, associates with U3 snoRNP and is required for $18 \mathrm{~S}$ rRNA biogenesis. EMBO J 19: 21152126

62. Wegierski T, Billy E, Nasr F, Filipowicz W (2001) Bms1p, a G-domain-containing protein, associates with Rcl1p and is required for $18 \mathrm{~S}$ rRNA biogenesis in yeast. RNA 7: 1254-1267

63. Henras AK, Plisson-Chastang C, O'Donohue MF, Chakraborty A, Gleizes PE (2015) An overview of pre-ribosomal RNA processing in eukaryotes. Wiley Interdiscip Rev RNA 6: 225-242
64. Gelperin D, Horton L, Beckman J, Hensold J, Lemmon SK (2001) Bm$\mathrm{s} 1 \mathrm{p}$, a novel GTP-binding protein, and the related Tsr1p are required for distinct steps of $40 \mathrm{~S}$ ribosome biogenesis in yeast. RNA 7: 12681283

65. Karbstein K, Jonas S, Doudna JA (2005) An essential GTPase promotes assembly of preribosomal RNA processing complexes. Mol Cell 20: 633-643

66. Delprato A, Al Kadri Y, Perebaskine N, Monfoulet C, Henry Y, Henras AK, Fribourg S (2014) Crucial role of the Rcl1p-Bms1p interaction for yeast pre-ribosomal RNA processing. Nucleic Acids Res 42: 1016110172

67. Horn DM, Mason SL, Karbstein K (2011) Rcl1 protein, a novel nuclease for $18 \mathrm{~S}$ ribosomal RNA production. J Biol Chem 286: 34082-34087

68. Wells GR, Weichmann F, Colvin D, Sloan KE, Kudla G, Tollervey D, Watkins NJ, Schneider C (2016) The PIN domain endonuclease Utp24 cleaves pre-ribosomal RNA at two coupled sites in yeast and humans. Nucleic Acids Res 44: 5399-5409

\section{Cyklazy 3'-końcowego fosforanu RNA}

\section{Witold Filipowicz ${ }^{\bowtie}$}

Friedrich Miescher Institute for Biomedical Research, Maulberstrasse 66, 4058 Basel, Switzerland

e-mail: witold.filipowicz@fmi.ch

Słowa kluczowe: 2' ,3'-cykliczny fosforan, cyklaza 3'-końcowego fosforanu, cyklaza RNA, ligaza RNA, RtcA, RtcB, Rcl1, składanie tRNA, reperacja RNA

\section{STRESZCZENIE}

Cząsteczki RNA zakończone 2', $3^{\prime}$-cyklicznym fosforanem są częstymi produktami metabolizmu RNA w komórce. Dla przykładu, 2',3'-cykliczny fosforan jest przejściowym lub końcowym produktem cięcia RNA przez różne endorybonukleazy. Wiele rybozymów również generuje cykliczny fosforan na $3^{\prime}$ końcu. Endonukleolityczna fragmentacja nie jest jednak jedynym sposobem produkcji molekuł zawierających 2',3'-cykliczny fosforan. Powstają one również w reakcji katalizowanej przez cyklazy 3'-końcowego fosforanu RNA (RtcA), enzymy występujące u Eukaryota, Bacteria i Archaea. Enzymy te przekształcają końcowy 3'-monofosforan w 2', $3^{\prime}$-cykliczny fosfodwuester w reakcji zależnej od ATP. Niniejszy artykuł omawia właściwości biochemiczne i strukturalne cyklaz 3'-końcowego fosforanu RNA oraz białek z rodziny Rcl1 o strukturze podobnej do cyklaz. Białka Rcl1 nie posiadają aktywności cyklazy lecz uczestniczą w biogenezie rybosomalnego RNA. 